\title{
The Extent of Use of Quality Practices By \\ Commercial Banks in Kenya
}

\author{
Nuria Mamo Hirbo \\ University of Nairobi, Kenya, nuriahirbo@gmail.com
}

\begin{abstract}
The study set out to examine service quality practices and customer satisfaction in commercial banks in Kenya. The research was motivated by the fact that there is limited research on effect of service quality on customer satisfaction in commercial banks especially Kenya. The objective of the study was to determine the extent to which service quality practices were adopted by commercial banks in Kenya. The literature review revealed mixed findings because some research employed five dimensions while others used six dimensions and nine dimension thereby giving different results. The study used cross sectional survey research design. Primary data was collected from both the operational manager and bank customers using a likert type scale questionnaire. The census was used to collect data from operation manager while systematic random sampling was used to collect data from customers. The finding was that most of the commercial banks in Kenya uses the servQual dimensions to some extent. On average, all the managers agree to use assurance, tangibility, empathy and reliability in strengthening customer relationship while they were uncertain on the use of responsiveness. It was also found that on average, all the managers were also uncertain to use assurance and responsiveness while on average they agree to practice tangibility, empathy and reliability in appreciating customers. The study recommends that management should pay attention to service quality and other factors which may lead to customer satisfaction.
\end{abstract}

Keywords: service quality, servQual dimensions, customer satisfaction.

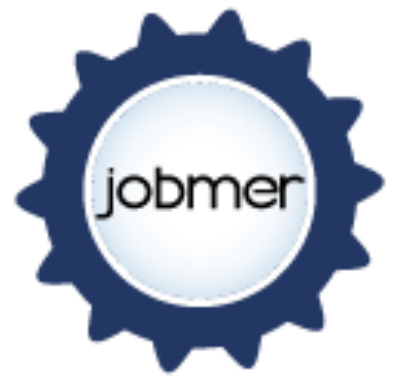

Journal of Business

Management and

Economic Research

Vol.2, Issue.3, 2018

pp.20-28

Doi: 10.29226/TR1001.2018.24 


\section{Introduction}

Organizations all over the world faces many challenges especially from the environment which include intense competition, changes in technology, changes in tastes and preferences of the customers, innovation and many others. To deal with these challenges firms are focusing their efforts on maintaining loyal customer base through customer satisfaction. For survival and prosperity, organizations must provide quality goods and services. Evaluations of quality in goods are easier when compared to that of services. Service quality distinguishing characteristics include intangibility, heterogeneity, and inseparability (Parasuraman, Zeithml \& Berry (1985) Gronroos (1990) describes service quality as having two dimensions that is, a technical or outcome dimensions and a functional or process related dimension. Spreng and Mackoy (1996) also argue that service quality and customers satisfaction are inarguably the two core concept that are at the crux of marketing theory and practice. Reichheld and Sasser (1990) on the other hand state that there is a positive relationship between customer loyalty and profitability. Kanishka (2006) argued that the nature of most service is presence of customer in the delivery process and the perception of quality is influenced by not only the service outcome but also the delivery process. Delivering quality service means conforming to customer expectations on a consistent basis (Lewis \& Booms 1983).

Service quality is very important to any organization because it is a route to competitive advantage and profitability. Quality superiority has been found to provide substantial performance related benefits such as customer loyalty, responsiveness to demand, market share growth and productivity (Berry \&Parasuraman, 1991). Bank service quality is usually perceived as a critical prerequisite for satisfying and retaining valued customers (Taylor \& Baker, 1994). Therefore organizations should first identify what the consumer perceives as service quality in order to successfully leverage service quality as a competitive edge. Service quality will enable organizations to make more sales which will in turn increase the profitability of the firm and hence improving the firm's image.

Several theories help to show the need by firms to survive in this dynamic world. Survival based theory (Spencer, 1985) emphasized on the notion that by following the principle of nature, only the best and the fittest of competitors will win, which in the end would lead to the improvement of the social community as a whole. Resource-based view (Penrose, 1959) states that the source of firm's competitive advantage lies in their internal resources, as opposed to their positioning in the external environment. The resource-based view of the firm predicts that certain types of resources owned and controlled by firms have the potential and promise to generate competitive advantage and eventually superior firm performance. Bain (1968) argues that according to the Market-Based View (MBV) the industry factors and external market orientation are the primary determinants of firm performance.

In Kenya, the banking sector plays a dominant role in the financial intermediation, particularly with respect to mobilization of savings and provision of credit (Were \& Wambua, 2013). Though performing their functions they are faced by tremendous changes in innovation and financial service environment as well as liberalization that have increased competition and interminable variety of product. Therefore to reduce the effect of these challenges they are forced to move from a producer oriented definition of competitiveness to one that recognizes the banks' ability to manage the linkage between activities and customers. To achieve this, they have to provide quality services to customers by monitoring and evaluating processes at each stage to ensure that customers get value for any services provided. Quality services leads to Customer satisfaction. This is very crucial as customers remain loyal to company's product if the products meet their perceived taste and preferences. 
According to Kenya bank supervision report (Sept, 2014) the banking sector comprised 43 commercial banks, 1 mortgage finance company, 9 microfinance banks, 7 representative offices of foreign banks, 94 foreign exchange bureaus, 7 money remittance providers and 2 credit reference bureaus. The Kenyan Banking Sector registered enhanced improved performance with the size of net assets standing at Ksh. 3.08 trillion, loans and advances worth Ksh. 1.91 trillion, while the deposit base was Ksh. 2.25 trillion and profit before tax of Ksh. 104.54 billion as at 30th September 2014. Over the same period, the number of bank customer deposit and loan accounts stood at 26,603,385 and 4,068,304 respectively. The banking sector's aggregate balance sheet increased by 3.7 percent from Ksh. 2.97 trillion in June 2014 to Ksh. 3.08 trillion in September 2014. The sector's gross loans and advances grew from Ksh. 1.78 trillion in June 2014 to Ksh. 1.91 trillion in September 2014, translating to a growth of 7.3 percent.

Kenya Financial access survey (2013) further indicates that access to formal financial services has increased significantly, with $32.7 \%$ of the adult population accessing financial services from the formal, prudentially regulated financial institutions, $66.7 \%$ of adults accessed financial services from any type of formal financial provider, The proportion of the financially excluded dropped from $39.3 \%$ in 2006 to $25.4 \%$ of the adult population in 2013 while the proportion of the population using informal financial services has declined to $7.8 \%$ from $33.3 \%$ in 2006 .

Despite the above positive development, the banks are still faced with the challenges of satisfying customers' needs due to their changing tastes and preferences. Further, banking sector is also faced with challenges of managing processes because some processes do not involve in directly adding value to customers. It is with this respect that service quality ensures that the needs of customers are identified so as to meet or even exceed the expectations of the customers. Also service quality enables the banking sector to concentrate on only those processes that adds value to them so as to be efficient and effective because quality ensures zero defects in making banking transactions.

ADB (2014) argue that despite the stagnation of the number of commercial banks in Kenya since 2008 , there is improved quality of financial services and expanded access. However, a KPMG survey (2013) maintains that there is still much further to go to meet the expectations of customers. It further contends that the customers are more interested in service quality in making their banking decisions. Further, bank supervision report (Sept, 2014) observed that the banking sector in Kenya experienced enhanced improvement in performance both in asset size and customer base.

The literature on service quality and customer satisfaction both locally and internationally are expansive. However, almost all studies focus only on an individual institution in the industry rather than the whole industry. Stellah (2013) researched on service quality and customer satisfaction of ABC bank in Uganda; Agbor (2011), researched on the relationship between customer satisfaction and service quality in three service sectors in Umea. Hussein and Aziz (2013) investigated e- banking service quality in one of the Egypt's banks, and Maddern, Maull and Smart (2007) examined customer satisfaction and service quality in UK financial services.

Again, most of the studies looked at service quality in firms other than banks. Duodu and Amankwa (2011) researched on an analysis and assessment of customer satisfaction with service quality in insurance industry in Ghana. Hellen (2014) examined service quality and customer satisfaction in certified public accountant training institutions in Nairobi Kenya. Wanjiku (2014) investigated the effect of service quality on customer satisfaction in the mobile telecommunication industry in Kenya. Manani, Nyaoga, Bosire, Mbati and Kongere (2013) examined service quality and customer satisfaction at Kenya Airways.

Further most of the literature reviewed in this study did not look at only the five dimensions of servqual model as proposed by Parasuraman et al., (1988). Isa (2008) examined the relationship 
between service quality perception and customer satisfaction sin Islamic banks using the six dimensions of service quality. It was found that compliance dimension was very crucial to Islamic banking. Stellah (2013), focused on all the dimensions of ServQual model to determine the service quality perceptions as she was interested in determining the various dimensions of service quality.

It was not clear whether the enormous growth of commercial banks in Kenya can be attributed to improvement in their service quality. Again, much has not been done on service quality and customer satisfaction in the banking sector as an industry. It is on this basis that the research investigates the effect of commercial banks service quality on customer's satisfaction in Kenya. Based on the above discussion the following research questions are posed: To what extent have commercial banks in Kenya adopted service quality practices? What is the relationship between service quality and customer satisfaction in commercial banks in Kenya?

This study is relevant to academicians because it adds knowledge to the existing framework of service quality and customer satisfaction. With respect to its academic value, the study accumulates knowledge that eventually outgrows the boundaries of academia and pervades management. This study contributes to existing theories by confirming or adding value to the relationships that are involved in customer satisfaction, service quality and SERVQUAL dimensions.

The study is also relevant to commercial banks because it helps them to redefine their corporate image to the one that is customer focused and emphasizes on service quality to satisfy customers. This study provides results that are useful to managers in banking organizations for strategic planning which enables banks to create a readiness profile in order to pinpoint the strength and weaknesses of their processes towards achieving quality and understand what dangers that can arise if they do not provide quality services to its customers.

To policy makers like the central banks, the finding and results of this study provides invaluable insights and a more reliable guide to monitoring the impact of the operations of the banking sectors while to other stakeholders, it provides invaluable information that allows them to provide useful suggestions to the improvement in service delivery of their respective banking sectors in Kenya.

\section{Methodology}

The research employed cross sectional survey design because it allowed the collection of both service quality and customer satisfaction data simultaneously and also helped in identifying association between the two hence making conclusion about the population. Population of the study was all commercial banks operating in Kenya. As at 2014, there were 43 commercial banks (Bank Supervision Report, 2014).

A census of all the 43 banks was considered. One operation manager was selected from each bank who assisted in filling questionnaire on service quality practices. As the customer population is large, the following equation developed by Cochran (1963) was used to select the customers from the banks, given as

$\mathrm{n}=\frac{Z^{2} P(1-P)}{e^{2}}$

Where $\mathrm{n}$ is the sample size, $\mathrm{Z}$ is the abscissa of the normal curve that cuts off an area $\alpha$ at the tails, $\quad \mathrm{e}$ is the acceptable sampling error and $\mathrm{p}$ is the estimated proportion of an attribute that is present in the population( or maximum variability assumed to be 0.5 ).

The study assumed $95 \%$ confidence level and variability to be 0.5 . From the normal distribution table, the corresponding $\mathrm{Z}$ value is 1.96 and the significance level will be $5 \%$ giving the e value to be 0.05 . This give the customer size as 
$\mathrm{n}=1.96^{2} * 0.5(1-0.5) / 0.05^{2}=384$ customers

This implied that 9 customers were selected from each 43 banks. A systematic random sampling technique was used to select the respondents. The technique was chosen because the sampling frame is not numbered and the bank customers are not exactly known. The study employed primary data that was collected using structured questionnaires. There are two questionnaires, one for operation managers and the other for customers. Each questionnaire has two sections that is A and B. For operation managers, section A entails demographic information and section $B$ is about the service quality practices as per ServQual dimensions( reliability, assurance, tangibility, empathy and responsiveness).For customers, section A includes demographic information and section B involves the indicators of customer satisfaction like customer loyalty, strengthened relationship and degree of appreciation. A five-point Likert scale ranging from strongly agree $=1$ to strongly disagree $=5$ will be used to measure the items. One questionnaire was administered to each bank.

The data collected on the extent to which service quality practices based on SERVQUAL model are adopted by commercial banks in Kenya will be analyzed using descriptive statistics mainly the mean, standard deviation and Karl Pearson's correlation coefficient.

\section{Results}

The research sought to investigate the extent to which commercial banks have adopted service quality practices as per the ServQual dimensions like reliability, assurance, tangibility, empathy and responsiveness which was proposed by Parasuraman et al., (1985). The respondents were required to indicate the extent to which they agreed with the service quality practices. The responses were subjected to descriptive statistics and the findings were presented as follows:

\section{Extent of Adoption of Tangibility}

The findings on adoption of tangibility are presented in table 1.

Table 1: Tangibility

\begin{tabular}{lcc}
\hline Tangibility Activities & Mean & Std.Deviations \\
\hline $\begin{array}{l}\text { 1.Our bank has modern Equipment } \\
\text { 2.The physical facilities at our bank are visually } \\
\quad \begin{array}{l}\text { appealing. } \\
\text { 3.Employees at our bank are neat in appearance }\end{array}\end{array}$ & 1.87 & 1.074 \\
$\begin{array}{l}\text { 4. Materials associated with the service at our banks are } \\
\text { visually appealing }\end{array}$ & 2.67 & 1.446 \\
$\begin{array}{l}\text { 5. Our bank has convenient opening hours } \\
\text { Average }\end{array}$ & 2.53 & 1.358 \\
\hline
\end{tabular}

\section{Source: Research data, 2015}

It can be observed from the study results in table 1 above that the use of modern equipment by operational managers has a mean of 1.87 and a standard deviation of 1.074. This corresponds to approximately 2 on a likert scale implying that most of the respondents agreed on the use of modern equipment in quality improvements. On average, the respondents also agreed that the physical facilities of their bank are appealing. This is supported by a mean of 1.50 and a standard deviation of 0.731 . Neat appearance of employees has a mean of 2.67 and a standard deviation of 1.446. This confirms that most of the respondents were not sure on the neat appearance of employees in improving quality. Materials associated with the service are 
visually appealing has a mean of 2.53 and a standard deviation of 1.358 an indication that most of the respondents were not sure on the use of visually appealing materials in quality improvement. Finally our bank has convenient working hours has a mean of 3.27 which implies that most of the respondents are completely unsure on banks having convenient working hours.

\section{Extent of Adoption of Empathy}

The empathy result is as shown in table 2:

Table 2: Empathy

\begin{tabular}{lccc}
\hline Empathy Activities & Mean & Standard Deviation & N \\
\hline $\begin{array}{l}\text { Our banks always give customers individual } \\
\text { attention }\end{array}$ & 2.37 & 1.351 & 30 \\
$\begin{array}{l}\text { Our banks have operating hours convenient to } \\
\text { all customers }\end{array}$ & 1.97 & 1.129 & 30 \\
$\begin{array}{l}\text { Our banks have customer best interest at heart. } \\
\begin{array}{l}\text { Employees of our banks understand the specific } \\
\text { needs of our customers }\end{array}\end{array}$ & 3.10 & 1.23 & 30 \\
\hline \begin{tabular}{l} 
Average \\
\hline
\end{tabular}
\end{tabular}

Source: Research Data, 2015

It can be observed from the study results in table 2 above that our banks always give customers individual attention has a mean of 2.37 and a standard deviation of 1.351 . This implies that most of the respondents agreed on banks giving individual attention to customers. Our banks have operating hours convenient to all customers have a mean of 1.97 and a standard deviation of 1.129. This confirms that the respondents agreed on banks having operating hours convenient to customers. Our banks have customers best interest at heart has a mean of 2.23 and a standard deviation of 1.278 which confirms that most of the respondents agreed on banks having customs interest at heart. Employees of our banks understand the specific needs of our customers has a mean of 3.1 and a standard deviation of 1.517 implying that most of the respondents were not sure on whether the employees understand the specific needs of customers.

\section{Extent of Adoption of Reliability}

The findings on adoption of reliability are presented in table 3 below:

Table 3: Reliability

\begin{tabular}{|c|c|c|c|}
\hline Reliability Activities & Mean & $\begin{array}{l}\text { Standard } \\
\text { Deviation }\end{array}$ & $\begin{array}{l}\text { Sample } \\
\text { Size }\end{array}$ \\
\hline $\begin{array}{l}\text { When our bank promises to do something by a certain time, } \\
\text { they do. }\end{array}$ & 2.10 & 0.999 & 30 \\
\hline $\begin{array}{l}\text { When a customer has a problem, our bank will show a sincere } \\
\text { interest in solving it, }\end{array}$ & 2.8 & 1.349 & 30 \\
\hline Our bank will provide the service right the first time. & 1.50 & 0.651 & 30 \\
\hline $\begin{array}{l}\text { Our bank will provide the service at the time they promise to } \\
\text { do so. }\end{array}$ & 1.70 & 0.777 & 30 \\
\hline Our bank insist on error free records & 2.63 & 1.497 & 30 \\
\hline
\end{tabular}

Source: Research data, 2015 
The findings from the study reveal that most of the respondents agreed that their banks normally fulfill promises. This is supported by a mean of 2.10 and a standard deviation of 0.995.The banks are having interest in solving customer problems has a mean of 2.80 and a standard deviation of 1.349. This corresponds to approximately 3 on a likert scales implying that most of the respondents were not sure on whether banks were having interest in solving customer problems.

Our bank will provide service right the first time has a mean of 1.70 and standard deviation of 0.651.Corresponding to approximately 2 on a likert scale indicating that on average most of the respondents agreed on providing service right the first time by their banks.Our bank provides service at the time they promise has a mean of 1.50 and a standard deviation of 0.777 . This confirms that most of the respondents agreed on timely provision of service by their banks. Our bank insists on error free records has a mean of 2.63 and a standard deviation of 1.497 indicating that most of the respond

\section{Extent of Adoption of Responsiveness}

The findings on adoption of responsiveness are presented in table 4 below.

Table 4: Responsiveness

\begin{tabular}{lrrr}
\hline Responsiveness Activities & Mean & Std. Deviation & N \\
\hline $\begin{array}{l}\text { Employees of our bank tell customers when service } \\
\text { will be performed. }\end{array}$ & 4.00 & 1.083 & 30 \\
$\begin{array}{l}\text { Employees of our bank are always willing to help } \\
\text { customers. }\end{array}$ & 3.13 & 1.279 & 30 \\
$\begin{array}{l}\text { Employees of our bank gives prompt service to } \\
\text { customers. }\end{array}$ & 3.20 & 1.297 & 30 \\
$\begin{array}{l}\text { Employees of our bank are never too busy to } \\
\text { respond to customers' request. }\end{array}$ & 1.97 & 1.189 & 30 \\
\hline Average & & & \\
\hline
\end{tabular}

Source: Research data, 2015

It can be observed from the study results in table 4 above that employees of our bank tell customers when service will be performed has a mean of 4.00 and a standard deviation of 1.083. This implies that most of the respondents disagreed about employees telling customers when services will be performed. On average, the respondents were not sure on whether employees were willing to help customers. This is supported by a mean of 3.13 and a standard deviation of 1.279 .

Employees of our bank give prompt service to customers has a mean of 3.20 and a standard deviation of 1.297 which confirms that most of the respondents were not sure on the prompt service offered by employees to customers. Employees of our bank are never too busy to respond to customers request has a mean of 1.97 and a standard deviation of 1.189 an indication that most of the respondents agreed on employees responding to customers

\section{Extent of Adoption of Assurance}

The findings on adoption of assurance are presented in table 5 below. 
Table 5: Assurance

\begin{tabular}{llcc}
\hline $\begin{array}{l}\text { Assurance Activities } \\
\text { The behavior of employees in our banks will instill }\end{array}$ & Mean & $\begin{array}{l}\text { Standard } \\
\text { Deviation }\end{array}$ & $\mathbf{N}$ \\
$\begin{array}{l}\text { confidence to our customers } \\
\text { Our customers feel safe when making transactions. }\end{array}$ & 3.17 & 1.516 & 30 \\
$\begin{array}{l}\text { Employees of our bank are consistently courteous of } \\
\text { our customers }\end{array}$ & 3.20 & 1.234 & 30 \\
$\begin{array}{l}\text { Employees of our bank have relevant knowledge on } \\
\text { how to answer customers. }\end{array}$ & 2.37 & 1.031 & 30 \\
\hline \begin{tabular}{l} 
Average \\
\hline
\end{tabular}
\end{tabular}

Source: Research data, 2015

The findings from the study reveal that most of the respondents agreed that the behavior of employees instills confidence to customers. This is supported by a mean of 2.33 and standard deviation of 1.516. Our customers' feels safe when making transactions has a mean of 3.17 and a standard deviation of 1.234. This corresponds to approximately 3 on a likert scale implying that most of the respondents were not sure whether customers feel safe when making transactions.

Employees of our bank are consistently courteous of our customers has a mean 3.20 and a standard deviation of 1.031 This implies that on average most of the respondents were not sure on employees being courteous with customers. Employees have relevant knowledge on how to answer customers has a mean of 3.27 and a standard deviation of 1.245, an indication that most of the respondents were unsure on employees having relevant knowledge to answer customers

\section{Conclusion, recommendation and Suggestions for Further Research}

The result was that the practice of ServQual dimensions was found to be different among different commercial banks in Kenya implying that the degree of use of ServQual dimensions varies depending on the indicators of customer satisfactions. For example on average all operations managers agreed to use ServQual dimensions on customer strengthening relationship. They agreed to use assurance, tangibility, empathy and reliability in strengthening customer relationship while they were uncertain on the use of responsiveness. Also on average they are uncertain on use of the ServQual dimension on customers' degree of appreciation. They were uncertain to use assurance and responsiveness while on average they agree to practice tangibility, empathy and reliability in appreciating customers. However, on average, all the managers agree to use tangibility, empathy and reliability but uncertain to practice assurance and responsiveness in creating customers loyalty.

The research was carried out on service quality and customer satisfaction in commercial banks in Kenya. Based on the findings the study recommends also areas to be researched further. First quality is a function of so many forces. Study recommends research on staff motivations on customer satisfaction. The effect of the size of the company and customer's satisfaction and other factors other than service quality on customer's satisfaction

Service quality leads to customer satisfaction, which in turn increases the organizational performance through profitability. It is on these regard that this study recommends that much to be done on the effect of service quality on organizational profitability. 


\section{References}

ADB (2014), Country strategy paper 2014-2018

Agbor, M. J. (2011). The Relationship between Customer Satisfaction and Service Quality: A study of three Service sectors in Umea- unpublished Master's Thesis.

Bain, J. (1968). Industrial Organization, John Wiley and Sons, New York.

Berry, L. (1995). "Relationship marketing of services growing interest, emerging perspectives", Journal of the Academy of Marketing Science, 23,236-45.

Berry, L.L. and Parasuraman, A. (1991). Marketing services- Competing through Quality, Free Press, New York, NY. Malhotra

Financial access survey report, 2013

Grönroos, C. (1990). Service Management and Marketing. Lexington Books, Lexington, MA, 1990

Hussein, M.I. and Aziz, R.A. (2013). "Investigating e-banking service quality in one of Egypt'sbanks: a stakeholder analysis". The TQM Journal, Vol. 25 Iss 5 pp. 557 - 576

KPMG. (2013). Africa Banking Industry Customer Satisfaction Survey, no. 121597

Lewis, R.C. \& Booms, B.H. (1983). The marketing aspects of service quality. In: L. Berry et al. (Eds), Emerging Perspectives on Ser vices Marketing (New York, AMA).

Maddern, HR., Maull, A., and Smart, P B. (2007). "Customer satisfaction and service quality in UK financial services". International Journal of Operations \& Production Management, 27 (9), 999- 1019.

Manani, T.O., Nyaoga, R.B., Bosire, R.M., Ombati T.O and Kongere T.O (2013), European Journal of Business and Management, 5, 22.

Isa.M. (2008)."An examination of the relationship between service quality perception and customer satisfaction", International Journal of Islamic and Middle Eastern Finance and Management, 1 (3), 191 - 209

Parasuraman, A., Zeithaml, V., and Berry, L. L. (1985). "A conceptual model of service quality and itsimplications for future research" Journal of Hospitality \& Leisure marketing, 3, 5.

Parasuraman, A., Zenithal, V.A. and Berry, L.L. (1988). “SERVQUAL: a multiple- item scale for measuring consumer perceptions of service quality", Journal of retailing, .64, 12-40.

Penrose, E.T. (1959). The Theory of Growth of the Firm, Blackwell, Oxford.

Reichheld, F. and Sasser, Jr., E. （1990). "Zero Defections: Quality Comes to Services", Harvard Business Review, 68 (5), 105-111.

Spencer, B.A (1985), "models of organizations and TQM: a comparison and critical evaluation", Academy of management Review, 19 (3), 446-71

Spreng, R.A. and MacKoy, R.D. (1996). "An empirical examination of a model of perceived service quality and satisfaction", Journal of Retailing, 72 (2), 201-14.

Stella, N. (2013). Service quality and customer satisfaction, a case study of ABC bank main branch. Unpublished master's theses.

Taylor, S.A. and Baker, T.L. (1994). "An assessment of the relationship between service quality and customer satisfaction in the formation of consumer purchase intentions", Journal of Retailing, 70 (2), 163-78. 